Journal of Experimental Agriculture International

14(4): 1-11, 2016; Article no.JEAl.30151

Previously known as American Journal of Experimental Agriculture

ISSN: 2231-0606

SCIENCEDOMAIN international

www.sciencedomain.org

\title{
Nitrogen and Phosphorus Uptake and Partitioning in Finger Millet as Influenced by Phosphorus Fertilization
}

\author{
Wekha N. Wafula ${ }^{1,2^{\star}}$, Nicholas K. Korir ${ }^{1}$, Henry F. Ojulong ${ }^{2}$, Moses Siambi ${ }^{2}$ \\ and Joseph P. Gweyi-Onyango ${ }^{1}$ \\ ${ }^{1}$ Department of Agricultural Science and Technology, Kenyatta University, P.O. Box 43844-00100, \\ Nairobi, Kenya. \\ ${ }^{2}$ International Crops Research Institute for the Semi-Arid Tropics (ICRISAT), P.O. Box 39063-00623, \\ Nairobi, Kenya.
}

Authors' contributions

This work was carried out in collaboration between all authors. Author WNW designed the study and wrote the first draft of the manuscript. Authors WNW, MS and JPGO reviewed the study design and all drafts of the manuscript. Authors NKK and HFO managed the analyses of the study. Authors WNW and JPGO managed the literature searches. All authors read and approved the final manuscript

Article Information

DOI: $10.9734 / J E A I / 2016 / 30151$

(1) Hugo Daniel Solana, Department of Biological Science, National University of Central Buenos Aires, $\frac{\text { Editor(s): }}{\text { Argentina. }}$ Reviewers:

(1) Marko Petek, University of Zagreb, Zagreb, Croatia. (2) Abin Sebastian, University of Hyderabad, India. Complete Peer review History: http://www.sciencedomain.org/review-history/16920

Original Research Article

Received $21^{\text {st }}$ October 2016 Accepted $10^{\text {th }}$ November 2016 Published 14 ${ }^{\text {th }}$ November 2016

\begin{abstract}
Finger millet (Eleusine coracana) production in Eastern Africa remains low due to a variety of factors including soil nutrient depletion. As intensive row-crop production evolves, improvements in managing soil nutrient quantity and availability of less renewable nutrients like $P$ becomes increasingly important. The yields in Kenya are typical of low input systems ranging below $1.0 \mathrm{tha}^{-1}$ against a potential of $5.0 \mathrm{t} \mathrm{ha}^{-1}$ in a season. In an attempt to overcome this constraint, On-station experiments were conducted at the Alupe research station during the long and short rain seasons of 2015 to investigate the influence of phosphate fertilizer rates $\left(0,12.5,25\right.$ and $\left.37.5 \mathrm{~kg} \mathrm{ha}^{-1} \mathrm{P}_{2} \mathrm{O}_{5}\right)$ on nutrient uptake and partitioning in finger millet. Partitioning of $\mathrm{N}$ and $\mathrm{P}$ was significantly influenced $(P<.05)$ by phosphate rates and variety. Most phosphorus and nitrogen content was
\end{abstract}


partitioned to the grains $(>30 \%)$ while the least to the roots $(<19 \%)$. Variety $\mathrm{U}-15$ had the greatest partitioning of nitrogen to the grains while the local variety, Ikhulule had the least. Application of phosphorus led to increase in the nitrogen and phosphorus uptake in finger millet with the most in the grains with a maximum of $106.5 \mathrm{~kg} \mathrm{ha}^{-1}$ on the $37.5 \mathrm{~kg} \mathrm{ha}^{-1} \mathrm{P}_{2} \mathrm{O}_{5}$ rate during the short rains while the roots had the lowest uptake with $16.9 \mathrm{~kg} \mathrm{ha}^{-1}$ and $22.1 \mathrm{~kg} \mathrm{ha}^{-1}$ in the long and short rains seasons respectively on the control. This study on nutrient use provides an opportunity to further improve $P$ fertilization to specific rates in relation to crops needs as farmers will be assured of greater yields, profitable and sustainable production. Limited use of $P$ fertilizer restricts the uptake of phosphorus and nitrogen as well as the balance in partitioning and recommends application of 25 $\mathrm{kg} \mathrm{ha}^{-1} \mathrm{P}_{2} \mathrm{O}_{5}$ with improved varieties.

\section{Keywords: Eleusine coracana; nutrient depletion; renewable nutrients; profitable.}

\section{INTRODUCTION}

Finger millet (Eleusine coracana) is an important food crop grown in low input farming systems by resource poor farmers in Eastern Africa. These farmers frequently suffer from high poverty, food insecurity, hunger and malnutrition [1]. Though limited attention is given to the crop by the national research systems, it is highly nutritious, it is hardy to abiotic and biotic stress compared to most cereals, has high malting quality only second to barley, and has good storability with minimal damage from storage pests and can be a great remedy to the challenges faced by smallholder farmers. The crop is grown on approximately 77,890 ha in Kenya [2] with a yield range of $500-1000 \mathrm{~kg} \mathrm{ha}^{-1}$ against a potential of $5,000 \mathrm{~kg} \mathrm{ha}^{-1}$ [3]. With appropriate research and proper dissemination of information to farmers, it is possible to achieve $3-4 \mathrm{t} \mathrm{ha}^{-1}$ as reported from on-farm and on-station studies in Kenya [4]. One of the major constraints in finger millet production is soil infertility. Improved agronomic management practices have aimed at matching plant nutritional needs with nutrients from the soil and fertilizer sources. These practices allow sustainable use of fertilizers by replacing removed nutrients without excessive application rates. Nutrients with high nutrient harvest index values remove more of that nutrient from the field than nutrients with low nutrient $\mathrm{HI}$ values and suggest a looming soil infertility crisis if adequate adjustments are not made in usage rates of fertilizers. It is suggested that phosphorus, the second most widely limiting nutrient in soil after nitrogen $[5,6]$, is a critical macronutrient for plant growth and development, particularly in tropical and subtropical soils, $\mathrm{P}$ deficiency is a major limitation to crop production [7]. Previous report by Stewart and Tiessen [8] had observed that less than $1 \%$ of soil $P$ is available for plant uptake, which is as a result of strong adsorption of phosphate by iron and aluminium oxides. There is a great disparity in distribution of phosphate uptake rate (Pi) between plant cells $(\mathrm{mM})$ and soil solution $(\mu \mathrm{M})$ [9]. Extremely low levels of available phosphorus in the rhizosphere therefore make it one of the major growth-limiting factors in many ecosystems [10]. The concentration of available $\mathrm{Pi}$ in soil seldom exceeds $10 \mu \mathrm{M}$ [11]. According to Smaling et al. [12], phosphorus has a significant role in sustaining and building up soil fertility, especially under intensive system of agriculture. Thus, its deficiency becomes an important chemical factor restricting plant growth in soils.

While $\mathrm{N}$ is the most limiting nutrient generally in soil, Delve et al. [13] has shown that deficiency of soil $\mathrm{P}$ reduces the efficiency of $\mathrm{N}$ use by crops. Experiment conducted on tomatoes reported the differences and similarities in the growth response of tomato plants to $\mathrm{N}$ and $\mathrm{P}$ limitation, and to their interaction [14]. These results suggest that the decrease in $\mathrm{N}$ concentration with increasing $P$ limitation may be mediated by a decrease in leaf cytokinin levels and is less likely due to decreased energy availability at low $\mathrm{P}$ conditions. Dry-mass partitioning to the roots was closely linearly related to the leaf reduced- $\mathrm{N}$ concentration. However, treatments that were severely P limited deviated from this relationship. Case studies have been conducted to examine responses of ecosystem biomass production to $\mathrm{P}$ addition, which vary significantly among different studies or ecosystems [15]. For instance, biomass has been reported to increase [16], decrease [17], or to change insignificantly [18] in response to external $\mathrm{P}$ input. According to $\mathrm{Li}$ et al. [19], such various and inconsistent results may be due to different ecosystem types, P fertilizer forms, or $\mathrm{P}$ addition rates. There was therefore, need to extend these investigative efforts to include other crops such as cereals and particularly finger millet. 
While fertilizer recommendation has become increasingly important to address the poor state of soils in Eastern Africa, information used to estimate $P$ and $N$ uptake, utilization and partitioning among organs under varying $P$ is limited, especially on finger millet. Although nutrient management is a complex process, understanding the allocation of nutrients by finger millet crop under $P$ stress presents opportunities to optimize fertilizer rates. This realization therefore led to the present study which aimed at evaluating the optimal phosphorus fertilizer rates that is effective in $\mathrm{P}$ and $\mathrm{N}$ allocation to the grains to improve yields and quality of finger millet and to an extent, reduce fertilizer waste and environmental pollution.

\section{MATERIALS AND METHODS}

\subsection{Site Description}

Two field experiments were conducted during the 2015 long and short raining seasons at Alupe Crops Research Station in Busia County. The site lies on Latitude $0^{\circ} 30 " \mathrm{~N}$ and Longitude $34^{\circ}$ 07' 50.02" E with an elevation of $1157 \mathrm{~m}$ A.S.L. The top soil of the experimental site was sandy clay loam with nutrient content of $0.08 \% \mathrm{~N}, 8$ ppm P, $0.74 \%$ organic carbon and $0.3 \mathrm{Meq} / 100 \mathrm{~g}$ exchangeable acidity [20].

\subsection{Experimental Layout and Design}

The experiment was laid out in a Randomized Complete Block Design in Factorial arrangement with three replicates. The treatments comprised of four phosphate fertilizer rates as triple superphosphate $\left(0,12.5,25\right.$ and $37.5 \mathrm{~kg} \mathrm{ha}^{-1}$ $\mathrm{P}_{2} \mathrm{O}_{5}$ ) and three finger millet varieties (U-15, P224 and a local check, Ikhulule). The experimental units measured $4 \mathrm{~m}$ long and $2 \mathrm{~m}$ wide with a $2 \mathrm{~m}$ pathway between them. During the onset of each season the study field was ploughed, re-ploughed and harrowed and demarcated into the 36 experimental units. Sowing during the long rains was done on March $30^{\text {th }}$ and $27^{\text {th }}$ September for the short rains by drilling. The triple superphosphate was applied according to the specific treatments and no fertilizer was applied on the control. After four weeks Urea was top-dressed in a blanket rate of $50 \mathrm{~kg} \mathrm{ha}^{-1} \mathrm{~N}$. The crop was harvested at physiological maturity on $11^{\text {th }}$ August 2015 and $15^{\text {th }}$ February 2016 for the long and short rain seasons, respectively.

\subsection{Plant Tissue Analysis and Data Collection}

At harvesting, all parts from ten plants from each experimental unit were separated from the plant and dried in an oven at $75^{\circ} \mathrm{C}$ to constant weights which were then weighed and recorded. Plant samples were then analyzed for $\mathrm{P}$ and $\mathrm{N}$ contents. Total phosphorus was determined by the molybdenum blue colorimetric method [21] and total nitrogen was determined by the microKjeldahl digestion [22]. Leaf, stem, panicle and root phosphorus and nitrogen uptake were calculated by multiplying the nutrient concentration by dry weights of the respective plant parts. The total amount of $\mathrm{P}$ and $\mathrm{N}$ uptake was calculated by summing the content of each element in all the plant parts and extrapolated by the amount of nutrient in plant material by the biological yield in kilograms per hectare. Partitioning (\%) was calculated by equating the nutrients concentration in each plant part as a fraction to the total uptake by the plant and converted into a percentage.

\subsection{Statistical Analysis}

The data collected was subjected to Analysis of Variance (ANOVA) to test significance due to treatments and where found Fisher's Protected LSD test was used to separate the means at 5\% probability using GenStat statistical software Version 15.1.

\section{RESULTS AND DISCUSSION}

\subsection{Phosphorus Uptake and Partitioning}

The partitioning of phosphorus content in the plant parts differed significantly for both seasons (Fig. 1). There were also differences on the interaction between the phosphate treatments and varieties on the uptake of phosphorus (Table 1) and partitioning of $P$ in the finger millet plants. The grains contained most of the phosphorus with over $41 \%$ allocated to the grains during the short rains and $42 \%$ during the long rains in the control treatment (Fig. 1). Jungk and Barber [23] also reported that maize utilization of applied $P$ to the grain was greater at low $\mathrm{P}$ application rate, indicating that $P$ efficiency decreases as application rate increases. There was $26 \% \mathrm{P}$ partitioned to the leaves during the short rains in the $25 \mathrm{~kg} \mathrm{ha}^{-1} \mathrm{P}_{2} \mathrm{O}_{5}$ rate and $25 \% \mathrm{P}$ on all the treatments except the highest rate which had $24 \%$ during the long rain. On the other hand, the stems contained $19 \% \mathrm{P}$ during the short rains 
and $17 \% \mathrm{P}$ during the long rains with no significant differences between the $P$ treatments, while the roots contained the least content of $P$ for both seasons with $16 \%$ during each season. Interestingly, there was a clear trend in allocation of $P$ to roots and grain, where the roots exhibited the highest partitioning of $P$ with the highest rate of $P$ application as shown on Fig. 2.

The partitioning of $P$ follows a steady and predictive uptake rate from V6 through R6 due to the plants mechanism to switch $P$ partitioning by remobilization to reproductive parts at the expense of vegetative organs. Phosphorus requirement increases steadily after flowering and during ripening periods of cereals and during grain formation, translocation of $P$ to the grain has been documented to be about $75 \%$ of the total $P$ in the above ground parts [24]. Under $P$ deficiency, the amount available to the plant during grain formation definitely influences the $P$ content of the grain. In a study on corn, similar findings were reported where nutrients especially $P$ was found to be highly mobile and begins translocation to the grain at the R2 stage [25]. Phosphorus uptake was observed to increase with increasing rates in the finger millet crop. The control had more $\mathrm{P}$ channeled to the grains compared to the other parts. This is because the grains are the main sink of $P$ in finger millet and under limited $P$ conditions the plants channels most of the $P$ for grain filling. However, the plants had a lower total $\mathrm{P}$ uptake compared to the applied treatments because of the reduced growth due to the low $P$ efficiency under suboptimal $P$ conditions in the soil. This could be due to its relative unavailability initially, when applied to phosphorus deficient soils. Similar findings were reported by Fohse et al. [26].

The allocation of $\mathrm{P}$ on the different plant parts was significantly influenced by the interaction between variety and phosphate application rates for both seasons. The combination between the highest rate of $37.5 \mathrm{~kg} \mathrm{ha}{ }^{-1} \mathrm{P}_{2} \mathrm{O}_{5}$ and $\mathrm{P}-224$ elicited the greatest partition of phosphorus to the grains with $106.5 \mathrm{~kg} \mathrm{ha}^{-1}$, leaves and stems during the short rains season (Table 1). However, the same combination was also significantly the same to the combination between $\mathrm{P}-224$ and $25 \mathrm{~kg} \mathrm{ha}^{-1} \mathrm{P}_{2} \mathrm{O}_{5}$ that had $95.6 \mathrm{~kg} \mathrm{ha-}{ }^{1}$ phosphorus uptake in the grains during the short rains. The control showed the lowest phosphorus uptake in all the plant parts for both seasons in all varieties where the lowest $\left(16.9 \mathrm{~kg} \mathrm{ha}^{-1}\right)$ observed under variety U-15. Phosphorus concentration in grain was reduced when there was limiting $P$ in the soil.

This is due to the low supply of energy to meet the requirement by plants to take up nutrients from the soil and translocate them through the plant. Varietal differences were not observed for both seasons on the uptake of $P$ in the grains but

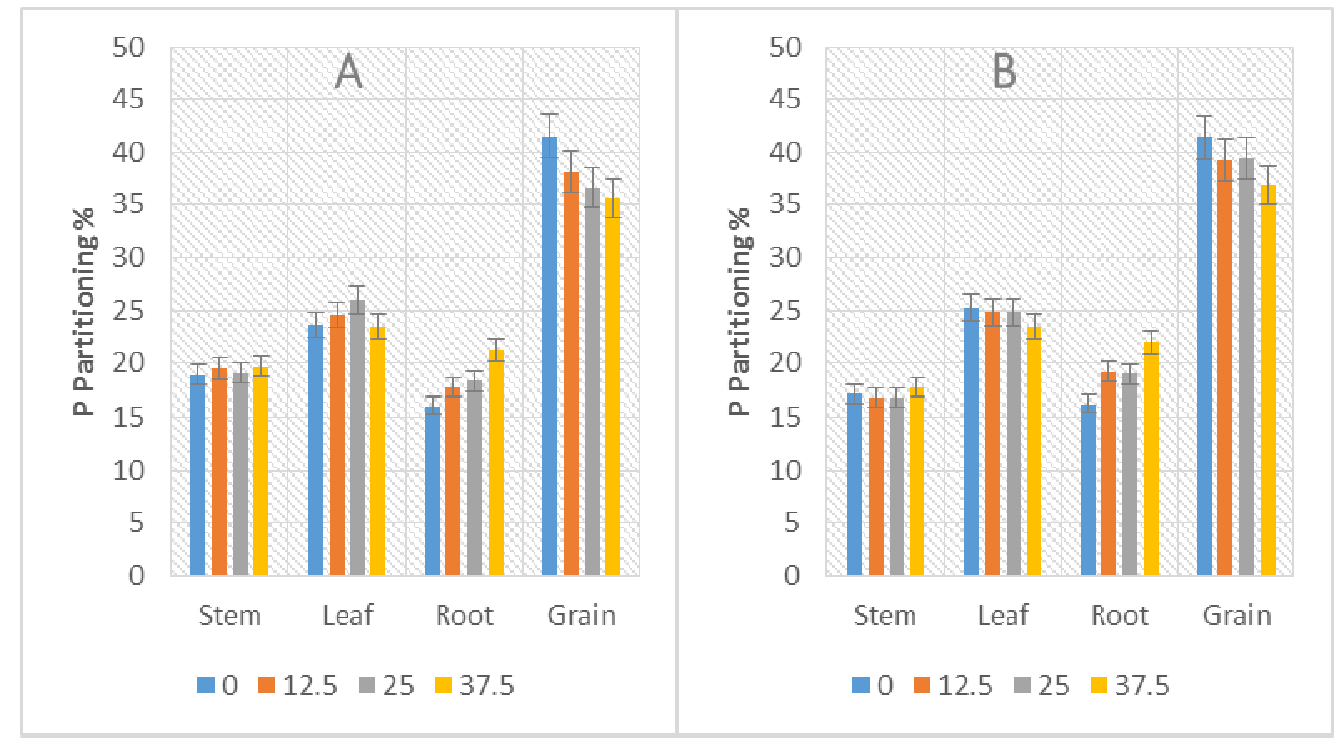

Fig. 1. The amount of $P$ partitioned to the stem, leaf, root and grain of finger millet during the short (A) and long (B) rainy seasons in Alupe 


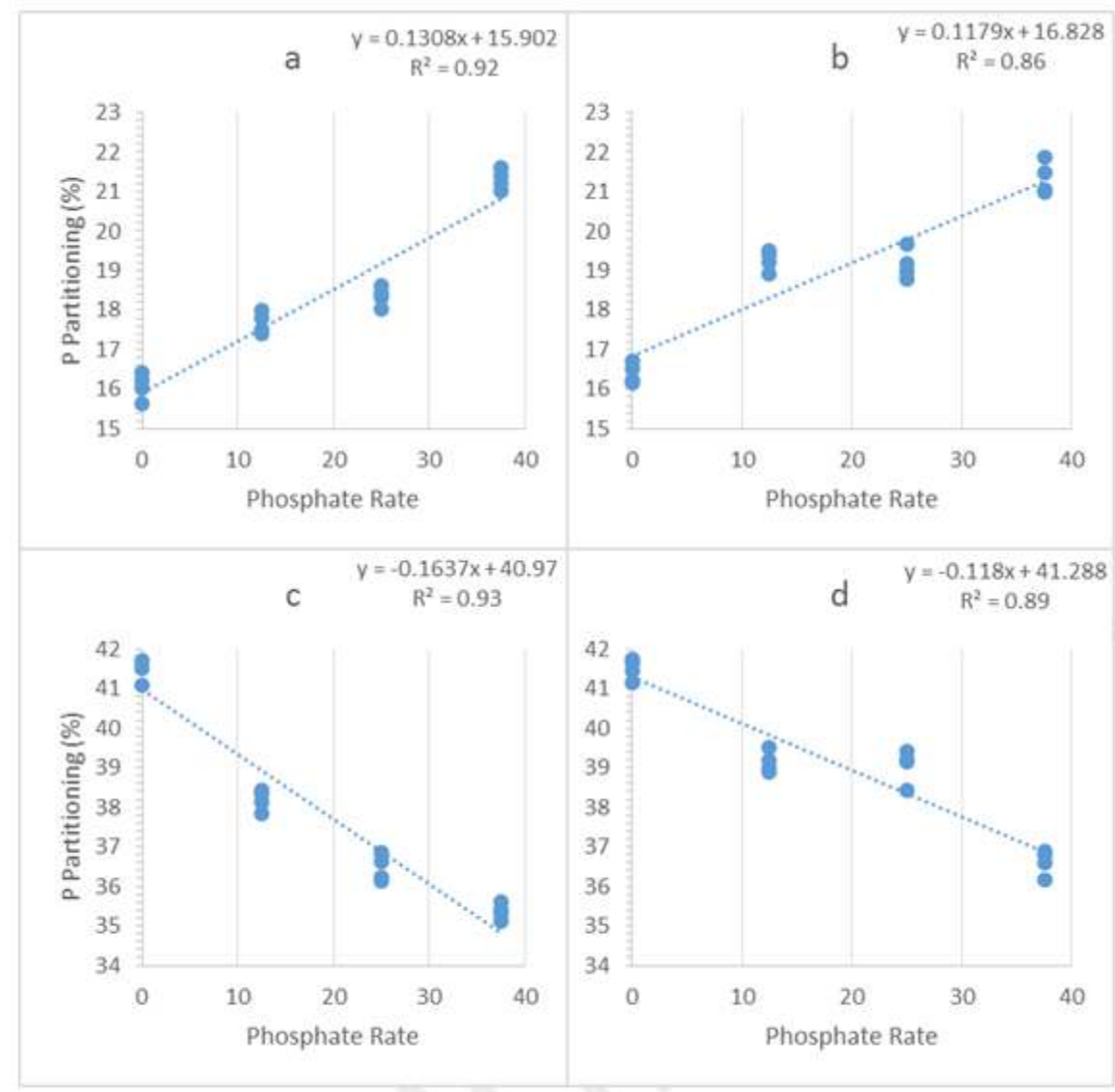

Fig. 2. Linear regression characterizing the relationship between applied phosphorus and partitioning percentage of $P$ in the root during the short (a) and long (b) rain seasons, and in the grain during the short (c) and long (d) rain seasons in Alupe

Table 1. Interaction effect between phosphate rates and variety on the phosphorus uptake in $\mathrm{kg} \mathrm{ha}^{-1}$ in Alupe

\begin{tabular}{|c|c|c|c|c|c|c|c|c|c|}
\hline \multirow[t]{2}{*}{ Variety } & \multirow{2}{*}{$\begin{array}{l}\mathrm{kg} \mathrm{ha}^{-1} \\
\mathrm{P}_{2} \mathrm{O}_{5}\end{array}$} & \multicolumn{2}{|c|}{ Stem } & \multicolumn{2}{|c|}{ Leaf } & \multicolumn{2}{|c|}{ Root } & \multicolumn{2}{|c|}{ Grain } \\
\hline & & $\begin{array}{l}2015 \\
\text { SR }\end{array}$ & $\begin{array}{l}2015 \\
\text { LR }\end{array}$ & 2015 SR & 2015 LR & $\begin{array}{l}2015 \\
\text { SR }\end{array}$ & $\begin{array}{l}2015 \\
\text { LR }\end{array}$ & 2015 SR & 2015 LR \\
\hline \multirow[t]{4}{*}{ U-15 } & 0 & $29.9^{C}$ & $18.8^{\mathrm{a}}$ & $39.4^{d}$ & $24.1^{a}$ & $22.1^{\mathrm{d}}$ & $16.9^{\mathrm{d}}$ & $66.2^{\mathrm{d}}$ & $39.4^{\mathrm{e}}$ \\
\hline & 12.5 & $37.0^{\mathrm{b}}$ & $20.4^{a}$ & $49.3^{c}$ & $25.7^{\mathrm{a}}$ & $28.2^{c}$ & $18.6^{\mathrm{d}}$ & $82.7^{\mathrm{b}}$ & $40.7^{e}$ \\
\hline & 25 & $38.6^{\mathrm{b}}$ & $26.4^{\mathrm{a}}$ & $52.0^{c}$ & $38.5^{\mathrm{a}}$ & $31.9^{\mathrm{b}}$ & $27.5^{\mathrm{b}}$ & $77.2^{c}$ & $61.6^{\mathrm{b}}$ \\
\hline & 37.5 & $41.7^{\mathrm{b}}$ & $22.6^{a}$ & $55.5^{c}$ & $32.5^{\mathrm{a}}$ & $31.2^{\mathrm{b}}$ & $23.6^{c}$ & $78.1^{\mathrm{c}}$ & $45.3^{\mathrm{d}}$ \\
\hline \multirow[t]{4}{*}{ P-224 } & 0 & $31.4^{\mathrm{bc}}$ & $19.1^{\mathrm{a}}$ & $40.9^{d}$ & $31.2^{\mathrm{a}}$ & $18.8^{\mathrm{e}}$ & $18.1^{\mathrm{a}}$ & $65.9^{a}$ & $49.3^{\mathrm{a}}$ \\
\hline & 12.5 & $33.8^{\mathrm{bc}}$ & $22.8^{a}$ & $45.1^{a}$ & $35.8^{\mathrm{a}}$ & $21.0^{\mathrm{a}}$ & $23.9^{c}$ & $75.6^{\mathrm{c}}$ & $55.3^{\mathrm{c}}$ \\
\hline & 25 & $48.8^{\mathrm{b}}$ & $26.5^{\mathrm{a}}$ & $66.4^{\mathrm{b}}$ & $40.4^{a}$ & $31.2^{\mathrm{b}}$ & $32.3^{a}$ & $95.6^{a}$ & $65.8^{\mathrm{b}}$ \\
\hline & 37.5 & $59.5^{a}$ & $29.0^{a}$ & $79.4^{\mathrm{a}}$ & $41.1^{\mathrm{a}}$ & $32.2^{\mathrm{b}}$ & $27.8^{\mathrm{b}}$ & $106.5^{\mathrm{a}}$ & $64.1^{\mathrm{b}}$ \\
\hline \multirow[t]{4}{*}{ Ikhulule } & 0 & $27.2^{\mathrm{C}}$ & $25.6^{a}$ & $32.7^{\mathrm{e}}$ & $37.8^{a}$ & $20.4^{\mathrm{d}}$ & $26.9^{\mathrm{b}}$ & $58.6^{\mathrm{d}}$ & $62.0^{\mathrm{b}}$ \\
\hline & 12.5 & $39.5^{\mathrm{b}}$ & $30.9^{\mathrm{a}}$ & $52.7^{c}$ & $43.0^{\mathrm{a}}$ & $32.0^{\mathrm{b}}$ & $32.2^{\mathrm{a}}$ & $84.6^{\mathrm{b}}$ & $72.5^{\mathrm{a}}$ \\
\hline & 25 & $43.8^{\mathrm{b}}$ & $31.2^{\mathrm{a}}$ & $60.9^{\mathrm{b}}$ & $43.6^{a}$ & $34.3^{a}$ & $31.2^{\mathrm{a}}$ & $85.7^{\mathrm{b}}$ & $73.5^{\mathrm{a}}$ \\
\hline & 37.5 & $39.7^{\mathrm{b}}$ & $22.3^{a}$ & $59.6^{\mathrm{b}}$ & $31.5^{\mathrm{a}}$ & $34.3^{a}$ & $26.0^{\mathrm{b}}$ & $90.3^{b}$ & $43.6^{\mathrm{d}}$ \\
\hline \multirow[t]{3}{*}{ Significance } & $\mathrm{V}$ & .043 & .26 & .006 & 0.07 & $<.001$ & .227 & .347 & .356 \\
\hline & $\mathrm{P}$ & .002 & .04 & .001 & .005 & $<.001$ & $<.001$ & .04 & $<.001$ \\
\hline & $V \times P$ & $<.001$ & .08 & .001 & .072 & $<.001$ & $<.001$ & .025 & .001 \\
\hline
\end{tabular}

on the roots Ikhulule was superior owing to its extensive root network while P-224 was superior in the leaves and stem. In converting the $\mathrm{P}$ uptake to economic yield P-224 seem to do 
better than the other varieties and this might be partly due to greatest uptake on the leaves that apparently associated with similar N (Fig. 2) that probably had a bearing on photosynthetic rate, leading to greater metabolic activity by the plants. The proportion of $\mathrm{P}$ concentration in the grains was relative to the total plant uptake and provided an estimate of partitioning and remobilizing efficiency and nutrient harvest index as observed in the combination between $37.5 \mathrm{~kg}$ $\mathrm{ha}^{-1} \mathrm{P}_{2} \mathrm{O}_{5}$ and $\mathrm{P}-224$. This indicates that the lower rate of $25 \mathrm{~kg}^{-1} \mathrm{P}_{2} \mathrm{O}_{5}$ which was insignificantly different from the highest rate in uptake of $P$ is more sustainable and reduces luxurious consumption by plants or loss to the environment. Lack of $P$ fertilization heavily impacted on the plants by increasing stress that generally lowered the quantities of the total nutrients partitioned and remobilized in the plant.

\subsection{Nitrogen Uptake and Partitioning}

Phosphorus application significantly increased the uptake of nitrogen for both seasons in Alupe as shown on Fig. 3. The Nitrogen partitioning was significantly influenced $(P<.05)$ by phosphate fertilizer rates and variety in both seasons. The grains contained the most nitrogen concentration with over $30 \%$ among the phosphate treatments and varieties. The nitrogen uptake increased with increasing $P$ rates in all the plant parts (Fig. 3) with the highest rate having the greatest nitrogen uptake for both seasons except in the grains for the short rains

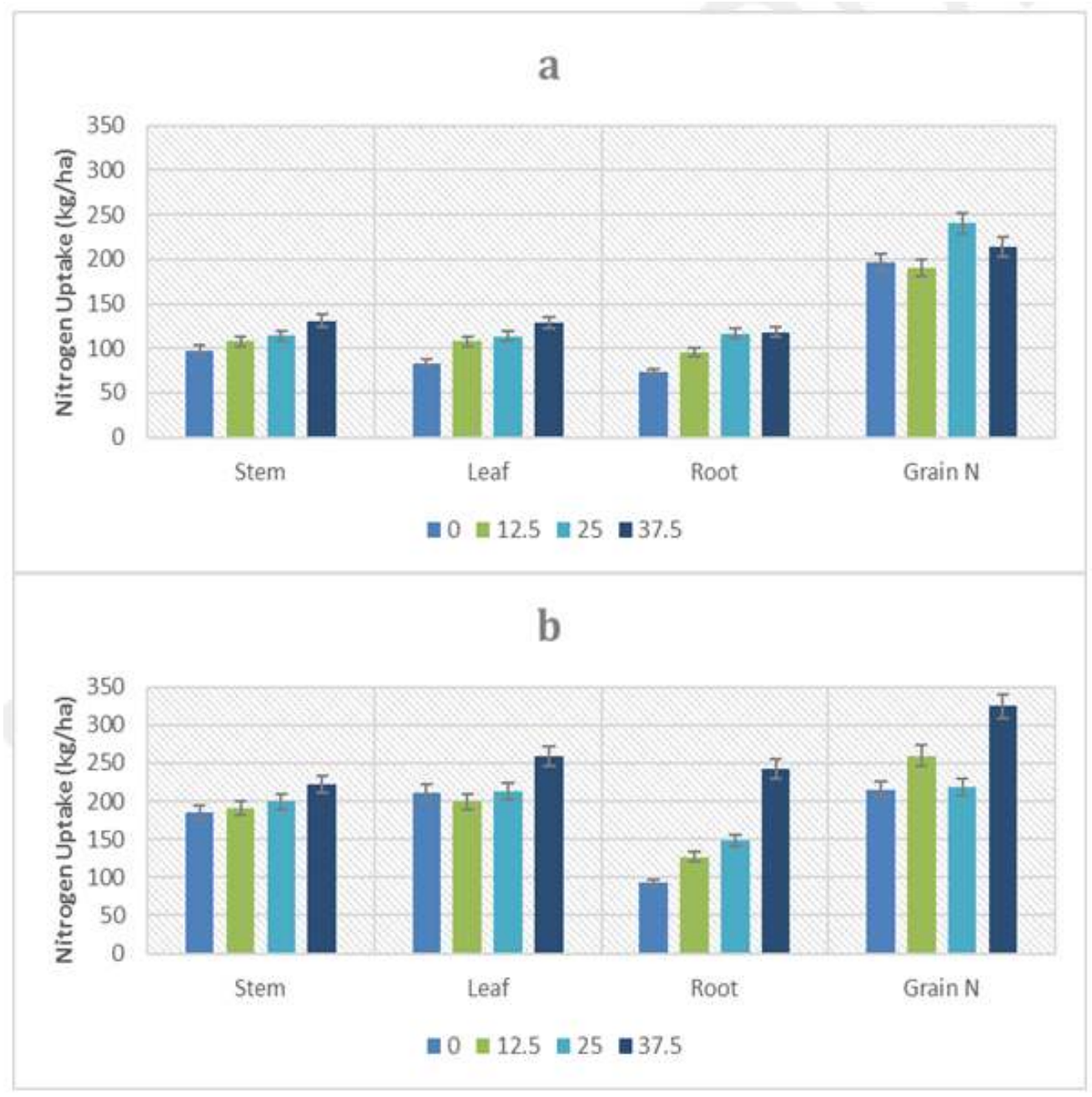

Fig. 3. The effect of phosphate rates on the uptake of nitrogen in plant parts of finger millet during the short rains (a) and long rains (b) in Alupe 
where the $25 \mathrm{~kg} \mathrm{ha}^{-1} \mathrm{P}_{2} \mathrm{O}_{5}$ had the greatest uptake. The leaves and stems contained between $23-30 \% \mathrm{~N}$ and the roots contained the least amount of nitrogen with less than $16 \% \mathrm{~N}$ in both seasons. Differential nitrogen partitioning was also reported by Graciano [27] with Eucalyptus spp. and there were clear difference among organs. According to the author [27], the nitrogen uptake and partitioning was even more influenced by $P$ rates than the $N$ supply. Their findings are in concurrence with the current study, where $\mathrm{N}$ uptake and partitioning increase with $\mathrm{P}$ rates.

The improved varieties U-15 and P-224 exhibited the highest partitioning rate of nitrogen to the grains for both seasons compared to the local variety, Ikhulule (Fig. 4). Variety U-15 did have the lowest uptake of nitrogen in the leaves, stems and roots for both seasons but proved to be the best by partitioning most of it to the grains compared to other organs for both seasons. Increased plant $\mathrm{N}$ content could also be higher due to the mineralization of organic $\mathrm{N}$ which was found to increase due to phosphate fertilizer application. The total nitrogen uptake also increased considerably due to the improvement in symbiotic $\mathrm{N}_{2}$ fixation, because it is well known that if the $\mathrm{P}$ nutrition of plants is improved, either through fertilization or biological means, symbiotic $\mathrm{N}_{2}$-fixation and the plant $\mathrm{N}$ contents are improved [28].

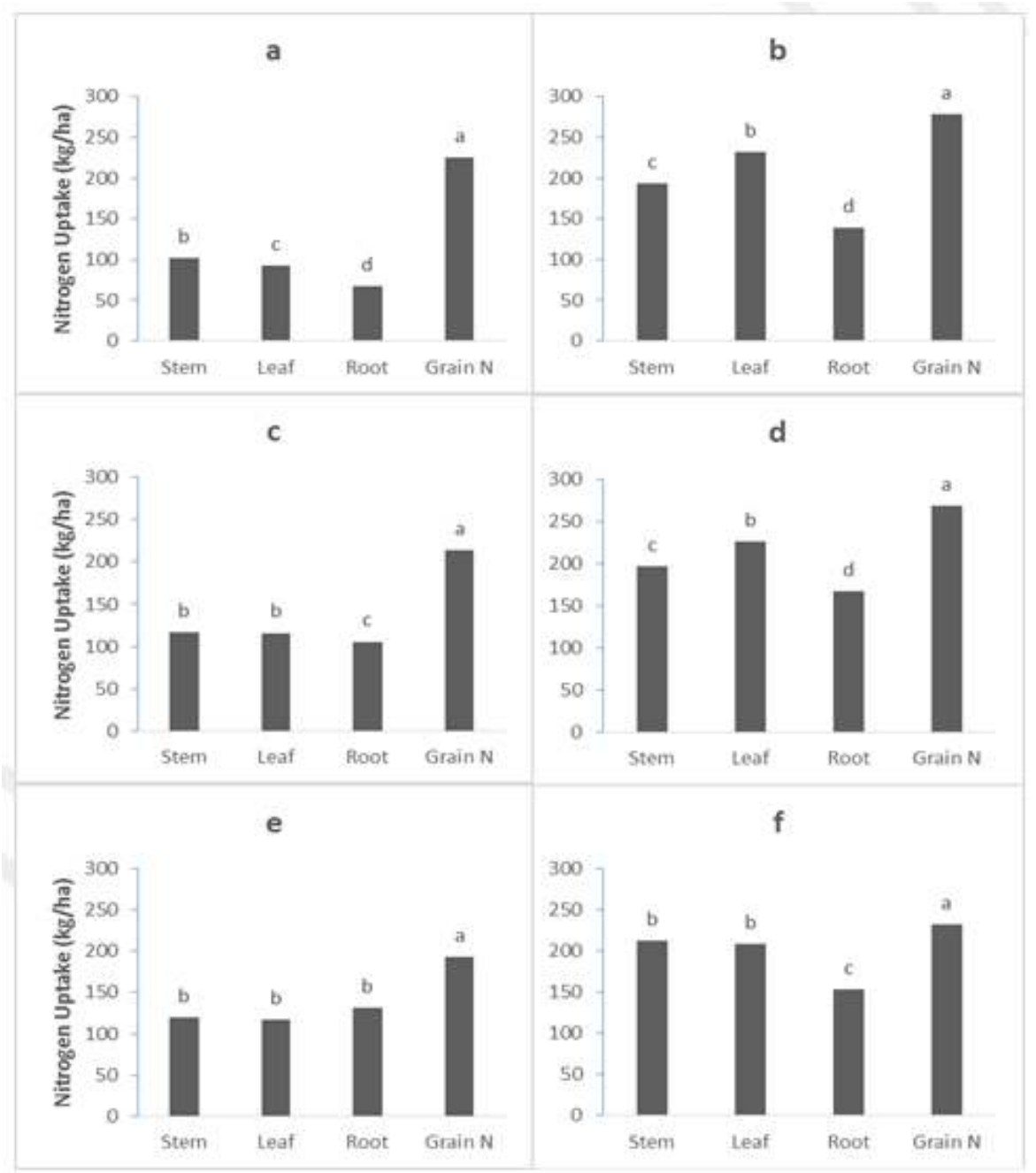

Fig. 4. Partitioning and uptake of nitrogen in plant parts of finger millet varieties $U-15(a \& b)$, P-224 (c \& d) and Ikhulule (e \& f) during the short and long rains respectively in Alupe 


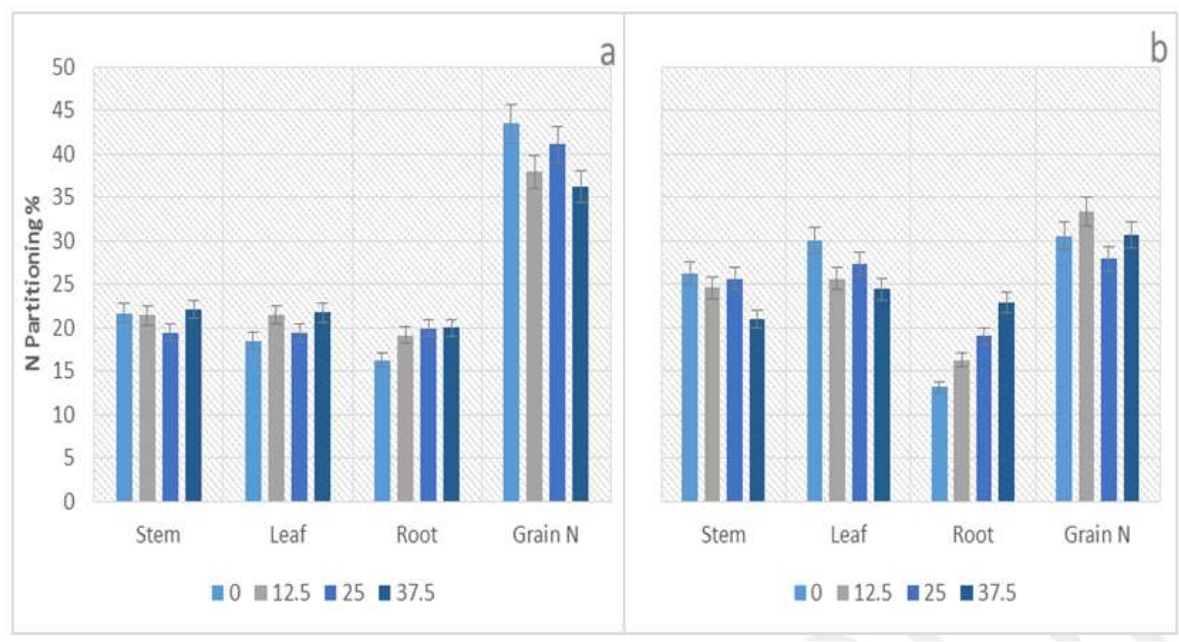

Fig. 5. The effect of phosphate rates on the partitioning of nitrogen in plant parts of finger millet during the long rains (a) and short rains (b) in Alupe

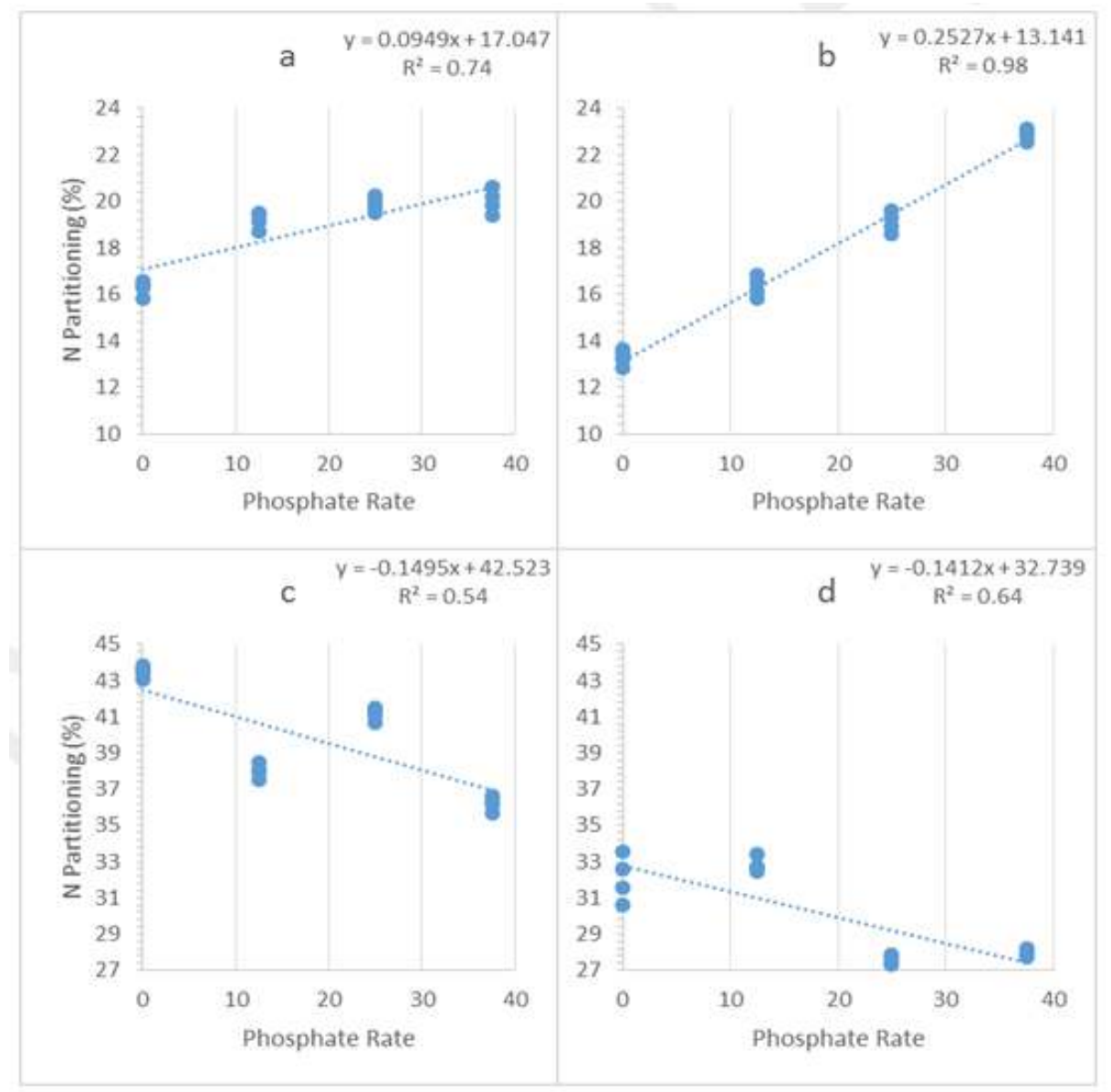

Fig. 6. Nitrogen partitioning percentage as a linear function of the applied phosphorus in the root during the short (a) and long (b) rain seasons, and in the grain during the short (c) and long (d) rain seasons in Alupe 
Application of phosphorus significantly $(P<.05)$ influenced the partitioning of nitrogen in the plant parts for both seasons (Fig. 5). The highest partitioning was to the grains but further increase in the phosphate rates led to a decrease in the amount of nitrogen partitioned as shown on Fig. 6 while increase of phosphate rate increased the amount of nitrogen partitioned in the roots.

This increase in partitioning to the roots with increasing $P$ was also observed with $P$ tissue partitioning (Fig. 2). Phosphorus also improves the root development and this leads to more uptake of nutrients. However, the control showed the highest $\mathrm{N}$ partitioned to the grains than the $\mathrm{P}$ treatments with up to $43 \%$ during the long rain season, while having the least nitrogen partitioned to the roots with $16 \%$ and $13 \%$ during the short and long rains seasons respectively. This is due to the plants mechanism to support reproductive growth at the expense of vegetative growth in low $\mathrm{P}$ conditions. Phosphate rates influenced the total nitrogen uptake in finger millet with applied plots being significantly superior to the control. Phosphorus leads to elongation of meristematic tissues and since it is a major constituent of ADP and ATP-the energy currency in metabolic activities in plants, it led to greater photosynthetic rates which increased dry matter production that accumulated more nitrogen. These observations conforms to findings by Sharma and Parmar [29]. The highest phosphorus level did have the highest $\mathrm{N}$ uptake in all the plant parts during the long rains season while the $25 \mathrm{~kg} \mathrm{ha}^{-1} \mathrm{P}_{2} \mathrm{O}_{5}$ treatment had the highest in the roots and grains during the short rains season. The greater $\mathrm{N}$-uptake with the application of only $\mathrm{P}$ is a factor to be considered in finger millet cultivation plans. The effects of fertilization at planting may continue to harvest [30] as attested by higher $\mathrm{N}$ content, which declines with $\mathrm{P}$ application, therefore, if the uptake of higher amounts of $\mathrm{N}$ in P-fertilized stands continues through time, this could reduce soil $\mathrm{N}$ stocks [31] in the soils, particularly under poor soil characteristic of peasant farmers. The higher $\mathrm{N}$ extraction at harvest could affect the sustainability of soil productivity [32], and this may, necessitate the need to carry out longer term experiments in order to study the changes in soil nutrient stocks as affected by fertilization with $\mathrm{P}$.

\section{CONCLUSION}

Limited availability of phosphorus restricted the uptake of nitrogen and phosphorus as well as the balance in partitioning. The nutrient uptake of $P$ and $N$ increased with increasing $P$ rates and once the efficient use of $P$ nutrient was found limited, the nutrient uptake started to decline. It was also found that phosphorus supply had influenced the uptake and partitioning in different plant organs but this was also dependent on finger millet varieties. There was more partitioning of $\mathrm{N}$ and $\mathrm{P}$ to the grain where there was limiting $P$. As more $P$ was added, then most of $N$ and $P$ was allocated to the roots. Since the increase in $\mathrm{P}$ supply led to further uptake of $\mathrm{P}$, there is need for caution to avoid continuous cultivation of finger millet as this can lead to excessive extraction of $\mathrm{N}$. The partitioning of $\mathrm{P}$ and $\mathrm{N}$ to the grain under low $\mathrm{P}$ application implies more export of nutrients with grains to the market yet the allocation to roots means that this will be recycled back to the soil. There is need to strike a balance between grain quality and by extension nutrient export and nutrient recycle and sustainable productivity of the soil where this study recommends $25 \mathrm{~kg} \mathrm{ha}^{-1} \mathrm{P}_{2} \mathrm{O}_{5}$ with improved varieties.

\section{ACKNOWLEDGEMENTS}

We would like to thank the International Crops Research Institute for the Semi-Arid Tropics (ICRISAT)-Nairobi for the financial support. The authors are also grateful to the Director-ESA and the Principal Scientist Dr. Eric Manyasa for their commitment to support the project. The entire ICRISAT staff in Nairobi and Alupe particularly Mr. Daniel Ajaku Otwani and Godfrey Wandera as well as the casuals in the field who made this work successful are also greatly appreciated. We are also much grateful to the Kenya Soil Survey for conducting the analysis and technical advice on analytical work.

\section{COMPETING INTERESTS}

Authors have declared that no competing interests exist.

\section{REFERENCES}

1. Chianu JN, Adesina A, Sanginga $P$, Batiano A, Chianu A, Sanginga N. Structural change in fertilizer procurement method: Assessment of impact in SubSaharan Africa. African J. of Bus. 2008;2 (3):065-071.

2. ICRISAT. Finger millet strategic plans Ethiopia, Kenya, Tanzania and Uganda 2012-2016. Harnessing Opportunities for 
Productivity Improvement of Sorghum and Millet (HOPE) Project report. ICRISAT, Nairobi; 2013.

3. Oduori COA. Breeding investigations of finger millet characteristics including blast disease and striga resistance in western Kenya. PhD Thesis, University of Kwazulu Natal, South Africa; 2008.

4. Oduori C, Kanyenji B. Finger millet in Kenya: Importance, advances in $R \& D$, challenges and opportunities for improved production and profitability. In Mgonja MA, Lenné JM, Manyasa E and Sreenivasaprasad S. (Eds). Proceedings of the first international finger millet stakeholder workshop, projects R8030 and R8445 UK Department for International Development- Crop Programme 13-14 Sept. 2005 at Nairobi. Patancheru 502 324, A.P. India. ICRISAT. ISBN. 2007;49-65.

5. Fosu-Mensah BY, Mensah M. The effect of phosphorus and nitrogen fertilizers on rain yield, nutrient uptake and use efficiency of two maize (Zea mays L.) varieties under rain fed condition on haplic lixisol of the forest-savannah transition zone of Ghana. Environmental Systems Research. 2006; 5:(22):1-17

6. Balemi T, Negisho L. Management of soil phosphorus and plant adaptation mechanisms to phosphorus stress for sustainable crop production: A review. J Soil Sci Plant Nutr. 2012;12(3):547

7. Mustonen PJ, Oelbermann M, Kass DCL. Using Tithonia diversifolia (Hemsl.) Gray, in a short fallow system to increase soil phosphorus avail-ability on a Costa Rican Andosol. J Agric Sci. 2012;4:91-100.

8. Stewart JWB, Tiessen H. Dynamics of soil organic phosphorus. Biogeo- chemistry. 1987;41:41-60.

9. Vance CP, Uhde-Stone C, Allan DL. Phosphorus acquisition and use: Critical adaptations by plants securing a nonrenewable resource. New Phytol. 2003; 157:423-457

10. Barber SA, Walker JM, Vasey EH. Mechanisms for the movement of plant nutrients from the soil and fertilizer to the plant root. J Agric Food Chem. 1963;11: 204-207.

11. Bieleski RL. Phosphate pools, phosphate transport, and phosphate availability. Annu Rev Plant Physiol. 1973;24:225-252.

12. Smaling EMA, Nandwa SM, Janssen BH. Soil fertility in Africa at Stake. In replenishing soil fertility in Africa. Ed Buresh BJ, Sanchez PA, Calhoun F. SSSA Special publication 51. Madison, Wisconsin, USA. 1997;47-63.

13. Delve RJ, Probert ME, Cobo JG, Ricaurte J, Rivera M, Barrios E, Rao IM. Simulating phosphorus resepose in annual crop using APSIM; model evaluation on contrasting soil types. Nutr Cycl Agroecosyst. 2009; 84:293-306.

14. De Groot CC, Marcelis LFM, van den Booogaard K, Kaisr WM, Lambers $\mathrm{H}$. Interaction of nitrogen and phosphorus nutrition in determining growth; 2003.

15. Huang WJ, Zhong GY, Liu JX. Nitrogen and phosphorus status and their influence on abovegrouns production under increasing nitrogen deposition in three successional forests. Acta Oecologica. 2012;44:20-27.

16. Gussewell S, Koerselman W, Verhoeren JTA. Biomass N: $P$ ratios as indicators of nutrients limitation for plant populations in Wetlands. Ecological Applications. 2003; 13:372-384.

17. Corbin J, Avis P, Wilbur R. The role of phosphorus and arbuscular mycorrhiza innoculum potential to elevated nitrogen inputs. Water, Air and Soil Pollution. 2003; 147:141-162.

18. Soudzilouskaia NA, Onipchenko VG, Cornelissen JHC, Aerts R. Biomass production, $\mathrm{N}$ : $\mathrm{P}$ ratio and nutrient limitation in Caucacian alpine tundra plant community. Journal of Vagetation Science. 2000;16:399-406

19. Li Y, Niu S, Yu G. Aggrevated phosphorus limitation on biomass production under increasing nitrogen loading: A metaanalysis. Global Change biology. 2016; 22:934-943

20. Jaetzold $R$, Schmidt $H$, Hornetz B, Shisanya C. Natural conditions and farm management information. $2^{\text {nd }}$ Edn. Part A: West Kenya. Sub Part Al Western Province. 2007;319.

21. Ryan J, George E, Rashid A. Soil and plant analysis laboratory manual. Second edition. Jointly published by international Center for Agricultural Research in the dry areas (ICARDA) and the National Agricultural Research Centre (NARC); 2001.

22. Yoshida S, Forno DA, Cock JH, Gomez KA. Laboratory manual for physiological 
studies of rice" (Third Edn.) International Rice Research Institute, Manila, Philippines. 1976;14-22.

23. Jungk A, Barber SA. Phosphorus uptake rate of corn root exposed to phosphate. Agronomy J. 1974;66:554-557.

24. Keulen Van H. Nutrient supply and crop response. Crop production as determined by nutrient availability In: Modelling of agricultural production; Weather, soils and crops. Agricultural University. Wagenigen, Netherlands. 1983;486.

25. Karlen DL, Flannery RL, Sadler EJ. Nutrient and dry matter accumulation rates for high yielding maize. J. Plant Nutr. 1987a;10:1409-1417.

26. Fohse D, Claassen N, Junk A. Phosphorus efficiency of plants. Plant Soil. 1998; 110:101-109.

27. Graciano C, Goya JF, Frangi JC, Guiamet JJ. Fertilization with phosphorus increases Soil nitrogen absorption in young plants of Eucalyptus grandis; 2006.
28. Reddy GB, Reddy S. Effect of organic manures and nitrogen levels in soil available nutrients status in maize-soybean cropping systems. Indian Society of Soil Science. 1998;51:78-80.

29. Sharma PK, Parmar DK. The effect of phosphorus and mulching on the efficiency of phosphorus use and productivity of wheat grown on a mountain Alfisol in the Western Himalayas, Soil Use and Management. 1998;14(1):25-29.

30. Schonau APG. Initial responses to fertilizing Eucalyptus grandis at planting are sustained until harvesting. SuidAfrikaanse Bosboutydskif. 1977;100:72-80.

31. Laclau JP, Bouillet JP, Ranger J. Dynamics of biomass and nutrient accumulation in a clonal plantation of Eucalyptus in Congo. Forest Ecol. Manage. 2000;128:181-196.

32. Fisher R, Binkley D. Ecology and management of forest soils. John Wiley and Sons Inc. 2000;489.

(c) 2016 Wafula et al.; This is an Open Access article distributed under the terms of the Creative Commons Attribution License (http://creativecommons.org/licenses/by/4.0), which permits unrestricted use, distribution, and reproduction in any medium, provided the original work is properly cited.

Peer-review history:

The peer review history for this paper can be accessed here: http://sciencedomain.org/review-history/16920 